\title{
Salt corrosion of brick walls
}

\author{
Yulia Ibraeva ${ }^{1,{ }^{*}}$, Philipp Tarasevskii ${ }^{1}$ and Andrey Zhuravlev $^{2}$ \\ ${ }^{1}$ Peter the Great St. Petersburg Polytechnic University, 195251, St. Petersburg, Russia \\ ${ }^{2}$ Moscow State University of Civil Engineering, Yaroslavskoe shosse, 26, Moscow, 129337, Russia
}

\begin{abstract}
The durability of buildings and structures is dependent on the quality of building materials and operating conditions. Clearly, during operation there may be adverse factors that were not considered on the design stage. These include a salt corrosion of the brick walls. It occurs reasonably often therefore the study of this subject is quite popular and important issue.
\end{abstract}

\section{Introduction}

At all times, the brick has been considered one of the most popular building material and remains so to this day. Today it is using not only for the construction of luxury multistorey homes and country cottages, but also in many other different structures. It is safe to say that among the many available on the market of new and advanced technologies, the brick as a material not just popular it is the undisputed leader. That is due to a number of his advantages, such as frost resistance, high strength, stability, good sound insulation, low moisture absorption, and many others $[5,6]$.

\section{Analysis of published data}

Water is one of the main causes of the destruction of the majority of highly porous building materials. After water enters the pores of the material, gradually dissolves crystal formation, which resulting in the weakening of connections between the pores and loss of strength of the material. The soluble salts which contained in the brickwork, the most dangerous because it promotes greater deterioration of the technical characteristics and aesthetic qualities of buildings and reduce its longevity [7-13].

Ceramic wall, masonry mortars, process water, atmospheric moisture, particularly in the form of acid rain are sources of soluble salts. The result of movement of soluble salts in the capillaries of the brickwork is the appearance of crystalline salt formations on the facade of the building, which called "efflorescence". Efflorescence can be considered an indicator of salt corrosion in brick in addition they spoil the appearance of the facade. Salting is one of the most common mechanisms of deterioration of porous materials and can cause serious damage to buildings and structures [14-18].

The most common causes of corrosion that is damage to the eaves and gutters; poorquality basement waterproofing; damage to the roof in the eaves area; drains, drain pipes;

\footnotetext{
*Corresponding author: ulchi412@mail.ru
} 
leakage of process fluids; the formation of condensation on the inner walls; structural failures related to the design of the roof; drains and gutters; straits salt solutions and heavy condensates inside the plant; groundwater penetration; crystallization in the pores of the brick walls of salts having hygroscopicity [19-26].
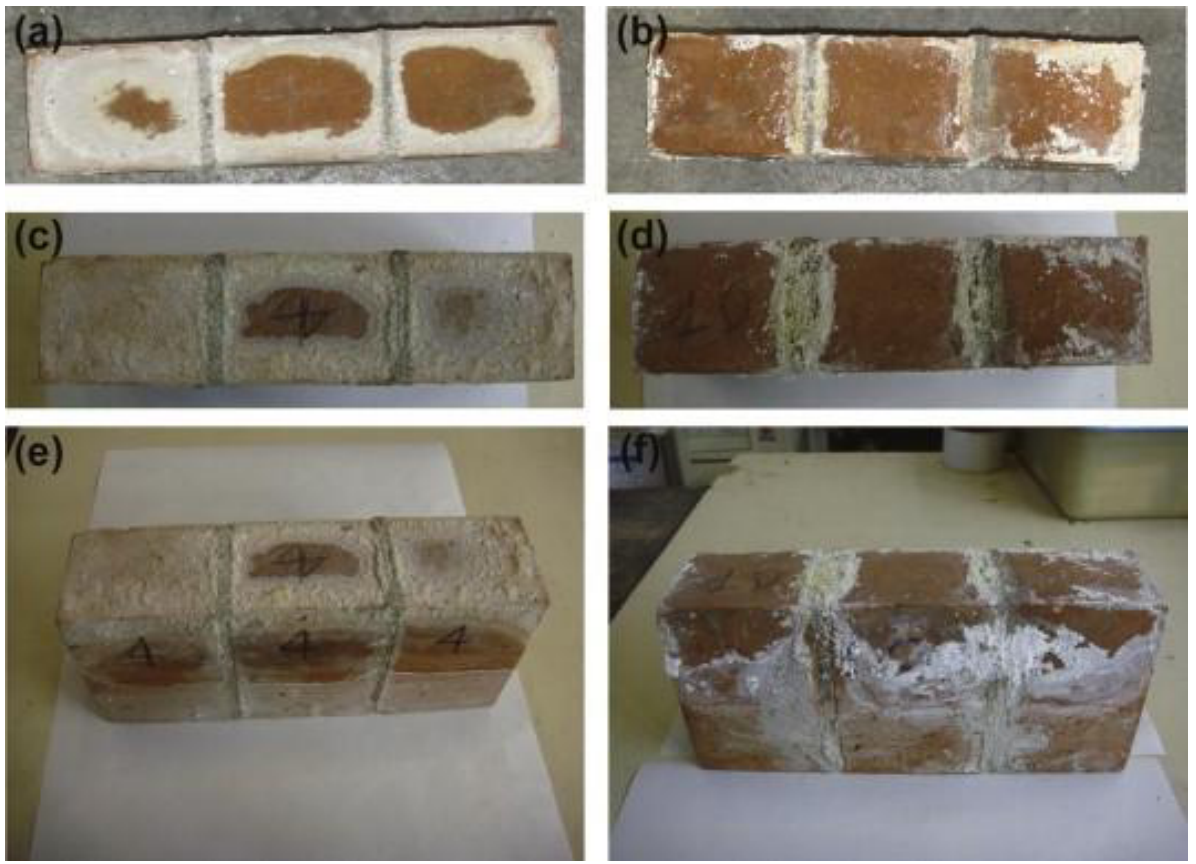

Fig. 1. Brick after several cycles of salting.

The selection of wall ceramic material produced based on the known methods [27]. By searching the bricks in the ground around the building, in spandrel, in attics, cellars, niches, the walls (in the presence of cracks); during the restoration or reconstruction of buildings and the full or partial dismantling of the walls; by sensing and disclosure of brick walls.

The method of X-ray diffraction analysis and chemical analysis revealed crystal hydrates possessing destructive properties with respect to the ceramic wall materials and masonry mortar: calcium aluminate sulfate hydrate $\left(3 \mathrm{CaO} \cdot \mathrm{Al}_{2} \mathrm{O}_{3} \cdot 3 \mathrm{CaSO}_{4} \cdot 31-32 \mathrm{H}_{2} \mathrm{O}\right)$, mirabilite $\left(\mathrm{Na}_{2} \mathrm{SO}_{4} \cdot 10 \mathrm{H}_{2} \mathrm{O}\right)$, epsomite $\left(\mathrm{MgSO}_{4} \cdot 7 \mathrm{H}_{2} \mathrm{O}\right)$, chlorite $\left(\mathrm{NaCl} \cdot 2 \mathrm{H}_{2} \mathrm{O}\right)$. In addition in the mass of destroyed materials (brick and masonry mortar) had been found other minerals multi-pass crystalline hydrates, which are the cause of salt corrosion: aluminite $\mathrm{Al}_{2}(\mathrm{OH})_{4} \mathrm{SO}_{4} \cdot 7 \mathrm{H}_{2} \mathrm{O}$, thaumasite $\mathrm{CaSiO}_{3} \cdot \mathrm{CaCO}_{3} \cdot \mathrm{CaSO}_{4} \cdot 15 \mathrm{H}_{2} \mathrm{O}$, alunogen $\mathrm{Al}_{2}\left(\mathrm{SO}_{4}\right)_{3} \cdot 18 \mathrm{H}_{2} \mathrm{O}$, liquid caustic soda $\mathrm{NaAl}\left(\mathrm{SO}_{4}\right)_{2} \cdot 12 \mathrm{H}_{2} \mathrm{O}[28,29]$.

In [30] the study was carried out, consisting of the following items:

1. Carrying out the procedure of artificial salting brick.
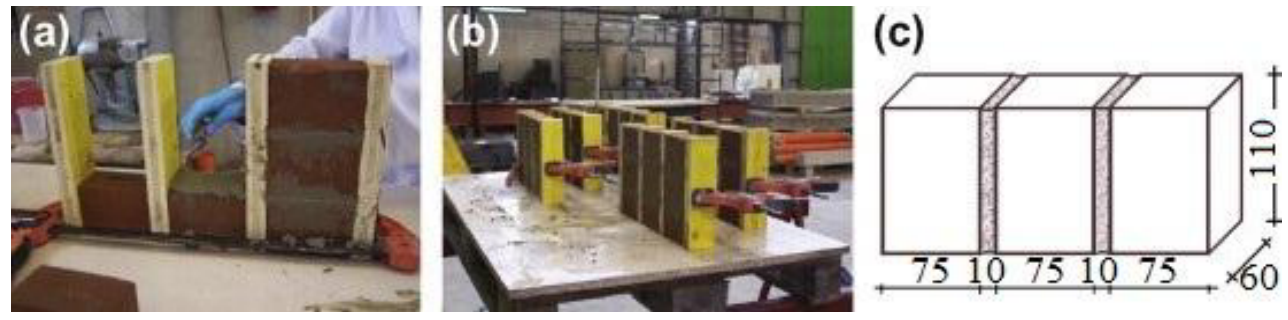

Fig. 2. Carrying out the procedure of artificial salting brick. 
2. Immersion the part of already solidified samples in water, and the other parts in a dry place, without any additional conditioning.

3. Identification of salt crystallization cycles by visual inspection.

4. Investigation the surface of bricks on the shear.
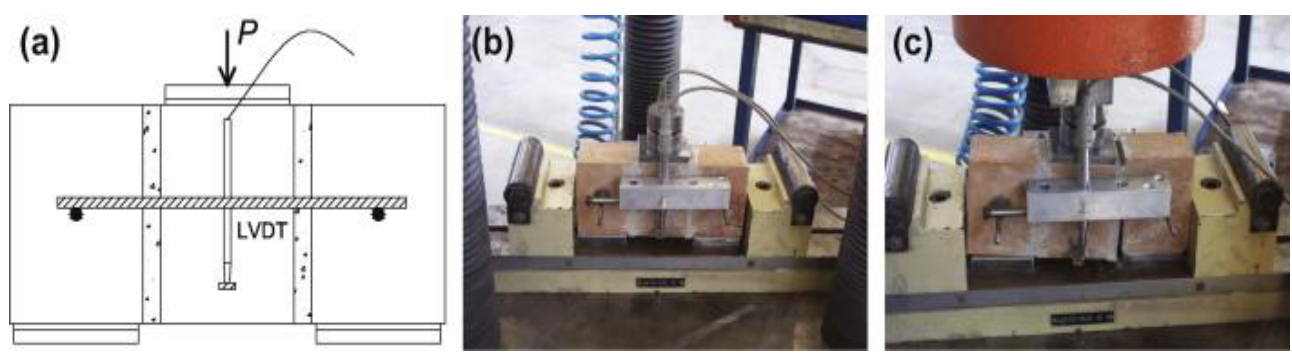

Fig. 3. Investigation the surface of bricks on the shear.

5. Comparison of key mechanical properties of the material.

6. Identification of the influence of the presence of salt in the structural behavior of masonry.

\section{Results}

Table 1. Results of research.

\begin{tabular}{|c|c|c|c|}
\hline Samples & Number of samples & Conditioning & The number of cycles \\
\hline REF & 3 & No & No \\
\hline SAT & 3 & The saturation by immersion in water & No \\
\hline W-1 & 3 & Cycles in water & 4 \\
\hline W-2 & 3 & Cycles in water & 10 \\
\hline CHL-1 & 3 & Cycles in a $1 \% \mathrm{NaCl}$ solution & 4 \\
\hline CHL-2 & 3 & Cycles in a $1 \% \mathrm{NaCl}_{\text {solution }}$ & 10 \\
\hline SUL-1 & 3 & Cycles in a $1 \% \mathrm{Na}_{2} \mathrm{SO}_{4}$ solution & 4 \\
\hline SUL-2 & 3 & Cycles in a $1 \% \mathrm{Na}_{2} \mathrm{SO}_{4}$ solution & 10 \\
\hline
\end{tabular}



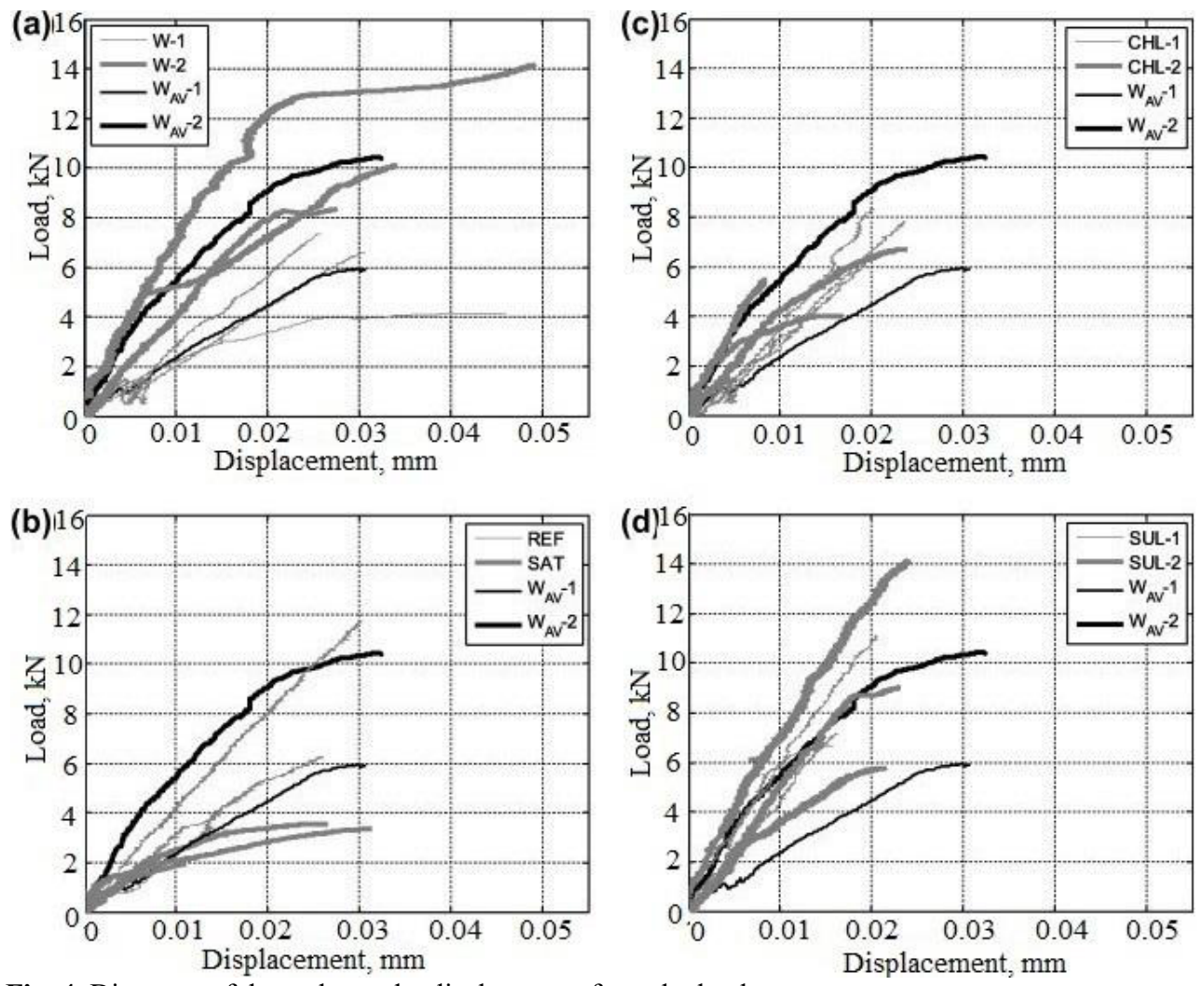

Fig. 4. Diagrams of dependence the displacement from the load.

\section{The method of calculation}

The actual strength masonry determined by the formula:

$$
R_{\mathrm{mas}}=k\left\{\frac{100+R_{\mathrm{br}}}{3\left(100+1.25 R_{\mathrm{br}}\right)} R_{\mathrm{br}}\left(1-\frac{0.2\left(0.3+R_{\mathrm{mor}}\right)}{R_{\mathrm{br}}}\right)\right\}
$$

where $R_{\text {mas }}$ - strength of masonry, $\mathrm{kgf} / \mathrm{cm}^{2}, R_{\mathrm{br}}$ strength brick, $\mathrm{kgf} / \mathrm{cm}^{2}, R_{\text {mor }}$ - strength of masonry mortar, $\mathrm{kgf} / \mathrm{cm}^{2}$; k-coefficient determined by the method of mathematical statistics, equal to 0.7 .

Standards for determining the change in the limits of material strength with resistance to compression are based on the literature [2, 3, 4], GOST 5802-80 and SNIP 11-22-81.

\section{Conclusions}

1. The formation of efflorescence on the masonry is determined by the following factors: Sources of soluble salts, humid-temperature conditions the brick walls, the pore structure of brick and ion exchange in masonry.

2. Has been detected mineralogical composition of efflorescence which produced in the masonry, which is characterized by the presence of mirabilite $\mathrm{Na}_{2} \mathrm{SO}_{4} \cdot 10 \mathrm{H}_{2} 0$, tenardite $\mathrm{Na}_{2} \mathrm{SO}_{4}$, mineral white $\mathrm{CaSO}_{4} \cdot 2 \mathrm{H}_{2} \mathrm{O}$, astrakanite $\mathrm{MgSO}_{4} \cdot \mathrm{Na}_{2} \mathrm{SO}_{4} \cdot 4 \mathrm{H}_{2} \mathrm{O}$, epsomite $\mathrm{MgSO}_{4} \cdot 7 \mathrm{H}_{2} \mathrm{O}$, wollastonite $\mathrm{CaSiO}_{3}$. 
3. The distribution of humidity in a brick wall, depending on its depth and temperature changes. The critical moisture content of the wall (3-5\%) and the humidity of the outside air $(60 \%)$, which cause the formation of efflorescence on the brick masonry;

4. The pore structure of the ceramic bricks, showing the distribution of the volume of open pores the size of their effective radii. The formation of efflorescence on the bricks of the most intensively whose predominant pore sizes having dimensions effective to $100 \mathrm{~nm}$ (mesopores).

5. The mechanism of the ion exchange occurring between the ceramic part of the mineralogical and migratory solution therein, causing the formation of sulphate efflorescence on brick masonry.

6. The development of salt corrosion of brickwork is determined by the following factors: the concentration and capillary suction of salt solutions, the pore structure of the components of the masonry, crystallization pressure that occurs in the pore space of the building materials and microorganisms.

7. It is shown that in emergencies under conditions of chemical production the water and dilute acid (sulfuric and acetic) which penetrate into the building construction in the short term (6 months) may reduce the strength of masonry components from 5 to $12 \%$.

8. Have been found the crystal salt hydrates in the masonry which possessing destructive properties: aluminite $\mathrm{Al}_{2}(\mathrm{OH})_{4} \mathrm{SO}_{4} \cdot 7 \mathrm{H}_{2} \mathrm{O}$, thaumasite $\mathrm{CaSiO}_{3} \cdot \mathrm{CaCO}_{3} \cdot \mathrm{CaSO}_{4} \cdot 15 \mathrm{H}_{2} \mathrm{O}$, alunogen $\mathrm{Al}_{2}\left(\mathrm{SO}_{4}\right)_{3} \cdot 18 \mathrm{H}_{2} \mathrm{O}$, liquid caustic soda $\mathrm{NaAl}\left(\mathrm{SO}_{4}\right)_{2} \cdot 12 \mathrm{H}_{2} \mathrm{O}$. Have been defined conditions and composed reaction equations showing their formation. It is noted that the volume of crystalline growth is directly proportional to the number of molecules of connected water.

9. Under conditions of sulphate corrosion ( $5 \% \mathrm{Na}_{2} \mathrm{SO}_{4}$ solution) the bearing capacity of the brick pillars through 6 months of test is reduced by at least $10 \%$; modulus of deformation - $15 \%$; elastic characteristics - $10 \%$.

10. The most important feature of the mechanism of brickwork is the crystallization pressure that occurs in the pore space of the building material. Taking into account the values of the crystallization pressure had been identified a number of salts in order of descending their degraded ability:

$$
\mathrm{Na}_{2} \mathrm{SO}_{4}>\mathrm{MgSO}_{4}>\mathrm{NaCl}>\mathrm{Na}_{2} \mathrm{CO}_{3}>\mathrm{CaSO}_{4} \text {. }
$$

11. Had been shown that the quantitative characteristic of salt corrosion of masonry is a change the strength of the brick walls. The strength of masonry buildings and monuments, which operation is carried out under conditions of sulfate corrosion in 100150 years is reduced to $20 \%$.

12. The expediency and efficiency of use of industrial by-products, on which base developed: ways to prevent salt raids on facial fired brick using waste containing $\mathrm{BaCO}_{2}, \mathrm{BaS}, \mathrm{BaSi}_{3}, 5 \mathrm{Ba} 0 \cdot 8 \mathrm{Si}_{2}, 2 \mathrm{Ba} 0 \cdot \mathrm{SiO}_{2}$ as well as the mineral goethite $-\mathrm{FeOOH}$ and hematite $\mathrm{a}-\mathrm{Fe}_{2} \mathrm{O}_{3}$ : a way to prevent efflorescence on brick masonry by introducing production waste lithopone in masonry mortars. Hydrophobization method of ceramic facing bricks prevents the formation of efflorescence on the brickwork and increases its resistance to frost, using resid from distillation of organosilicon compounds a method of waterproofing masonry walls by injection into the masonry hydrophobic solutions using electroosmosis.

\section{References}

1. V.V. Inchik, St. Petersburg 14, 17 (2001)

2. A. Elenkin, Engineering magazine 1, 1883 (2006) 
3. I.A. Fizdel, Defects in design and structures and methods of their elimination (Stroyizdat, Moscow, 1978)

4. L.I. Onishchik, Calculation of masonry with a ceramic lining (Gosstroiizdat, Moscow, 1960)

5. S.S. Podyapolskii, The restoration of monuments (Stroyizdat, Moscow, 1988)

6. V.V. Inchik, St. Petersburg 28, 115 (1998)

7. V.V. Inchik, Construction and reconstruction 3, 52 (2000)

8. A.I. Minas, Academy of Construction and Architecture of the USSR 2(4), 23-27 (1960)

9. I.V. Semenov, G.M. Florianovich, A.V. Khoroshilov Corrosion and corrosion protection ("Physical and mathematical literature", Moscow, 2010)

10. V.V. Babkov, N.S. Samofeev, A.E. Chuykin, Civil Engineering Magazine 8 (26), 35-40 (2011)

11. V.M. Gardener, Y.M. Gardener, Civil Engineering Journal 7(17), 10-13 (2010)

12. S.A. Starcev, Civil Engineering Journal 7 (17), 41-46 (2010)

13. N.G. Chumachenko, S.N. Evstefeev, Samara State Academy of Architecture and Construction 5, 83 (2001)

14. A.L. Bomshteyn, L.V. Verzhbitskaya, G. Zakharova, T.J. Krasilnikova, T.M. Kataev, V.A. Nikolaev, Natural Sciences Institute at the Perm State University 8, 13-18 (1996)

15. A.I. Bedov, V.F. Saprykin, DIA 19, 192 (1995)

16. V.V. Dorozhkin, Investigation of strength and deformability of masonry cinder blocks and stones, taking into account the time factor (Kand. diss., Odessa,1981)

17. V.A. Bench, S.A. Sementsov, Proceedings TSNIIKS, 6-45 (1978)

18. K.S. Shatemirov, Influence of salts on colloid-chemical properties of loess, clays and products based on them (Ilim, Moscow, 1967)

19. N.M. Khans, Strength and deformation of masonry (Stroyizdat, Moscow, 1993)

20. A.E. Charola, J Inst Conserv 39, 327-343 (2000)

21. P.B. Lourenco, E. Luso, M.G. Almeida, Build Environ 41, 223-234 (2006)

22. E. Rirsch, Z. Zhang, Constr. Build Mater 24, 1815-1820 (2010)

23. P. Lopez-Arce, E. Doehne, J. Greenshields, D. Benavente, D. Young, Mater Struct. 42, 827-848 (2009)

24. G.G. Amoroso, V. Fassina, Elsevier 19, 67 (1983)

25. J.R. Killip, D.W. Cheetham, Build Environ 22, 81-91(1984)

26. R.M. Espinosa-Marzal, G.W. Scherer, Acc. Chem. Res. 43, 897-905 (2010)

27. C. Rodriguez-Navarro, E. Doehne, Earth Surf. Proc. Land 24, 191-209 (1999)

28. G.W. Scherer, Cem. Concr. Res. 34, 1613-1624 (2004)

29. L. Binda, G. Baronio, Durabil Build Mater 4, 227-240 (1987)

30. C. Gentilini, E. Franzoni, S. Bandini, L. Nobile, Constr. Build. Mater. 37, 181-189 (2012) 